\title{
Audiovisual Representation in Spanish and European Election Debates
}

\author{
Sebastián Sánchez-Castillo \\ University of Valencia (Spain) \\ Esteban Galán-Cubillo \\ Polytechnic University of Valencia (Spain) \\ Arnau Gifreu-Castells \\ University of Girona (Spain)
}

The presence of ever more conflicting stances between Europhiles and Eurosceptics has revealed some audiovisual discourses unknown until now. The fragmentation of inconclusive narrative discourse and staged situations with a clear intent to clash all make it necessary to analyse in detail the role given by the audiovisual media to the European process of democratisation. This study addresses the audiovisual discourse in Spanish public television (TVE) with the intention of discovering how the different topics addressed in debates are dealt with in audiovisual production, and whether those topics have benefited from certain decisions by the production team that are subjective a priori. Using external codifiers, the intensity of each question has been checked and the result has been correlated with the dependent variables "[camera] shot with question while listening" and "shot with question with split screen". The variables have been subjected to descriptive analyses, correlation with hypotheses, and bivariate analyses using Pearson's correlation $(R x-y)$. The results indicate a clear difference in the modes of television representation between national Spanish and European debates. It is discussed whether this audiovisual differentiation may condition the perception that the audience may have of European politics.

Keywords: political communication, television production, audiovisual narrative, Euroscepticism. 

umerous studies on European integration have underlined the paradox that although the politics of the European Union (EU) have a considerable effect on the lives of citizens who are members of the EU, the process itself of formulating policies does not attract their attention (Banchoff and Smith, 2005; Lord and Beetham, 2002; Eriksen and Fossum, 2004). Several studies have attempted to explore the role of the media in this phenomenon. They have demonstrated that the media contribute to the creation of the above paradox (Gleissner and Vreese, 2005; Koopmans, 2007; Statham, 2008).

The elections to the European Parliament (EP) are considered to be a process focusing on national matters, or at least the European matters tend to be seen through a national lens (Marsh, 1998; Cayrol, 1991; Vreese, Lauf, and Peter, 2007; Brüggemann and Schulz-Forberg, 2009; Risse and Steeg, 2003), i.e. the so-called "second order" (Reif and Schmitt, 1980). The workings of European institutions are perceived as distant from local citizens' preferences and needs (Tsakatika, 2007), and factors such as the impossibility of determining the makeup of the executive and supranational bodies aggravate the feeling of detachment from the EU (Cremonesi et al., 2019). In addition to other reasons, this leads to low participation in the elections to the EU (Reif, Schmitt, and Norris, 1997) due to consideration of them as ambiguous, distant and having little influence on domestic life (Cremonesi et al., 2019).

Nevertheless, the idea is gaining ground that European matters such as economic and financial topics are being considered more strongly after the economic Great Recession as of 2008, gaining weight in EU countries' public agendas (Wilde, 2011; Statham and Trenz, 2012; Kriesi, 2016; Hutter and Kriesi, 2019). The idea of rejection or reaction is also growing, which in turn has accelerated the trend towards integration among European spheres and national debates, raising doubts about the "second order" and creating vertical processes of Europeanisation (interaction between national and European public spheres) and horizontal ones (interaction between the public spheres of European countries) in the EU's new role (Schmitt, 2005; Hobolt and Wittrock, 2011; Galpin and Trenz, 2018; Cremonesi et al., 2019). Authors like Koopmans and Erbe (2004) state that what really concerns people and is relevant to them has more to do with the ways of addressing the problems than the problems themselves, referring to Europeanisation as connections, relationships, interactions and mediations between the different stakeholders in the public sphere, i.e. "patterns of Europeanisation" (Cremonesi et al., 2019: 670). Europeanisation of the public sphere is perceived as a formula parallel to the national debate, which helps discuss the same problems concurrently and with the same relevance and routines in different European countries (Porte and Dalen, 2016; Königslöw, 2012; Pfetsch, Adam, and Eschner, 2008; Trenz, 2004; Maier, Strömbäck, and Kaid, 2011; Vreese et al., 2006). However, as Segesten and Bossetta (2019) point out, the reaction from Eurosceptics in the EU may have an undesired effect by giving debates in national media a stronger European dimension.

Europeanisation of public spheres is taking place in all of the traditional areas as well as in political communication channels in the web. The traditional audience for printed media, radio and television have a more Europhile profile than the 
audience in the social networks, who are more inclined towards Eurosceptic feelings (Highfield et al., 2013; Segesten and Bossetta, 2019). It is suggested that Europeanisation is fostered by those who oppose Europe more than by those who embrace it, insinuating the integrating potential of the reaction, seeing Eurosceptic voices "as an influential catalyst for cross-border dialogue" (Segesten and Bossetta, 2019: 379).

Public debate in the European Union (EU) takes place amid dynamics that involve different players in terms of the interactions and connections between different public spheres. It is a kind of Europeanisation understood as a multisided process (Cremonesi et al., 2019: 668). National media can help construct a public European sphere by concentrating on European topics and players, or on matters that took place in other European countries (Koopmans and Erbe, 2004; Cremonesi et al., 2019). It is possible to develop a European public sphere if the national media addresses topics and stakeholders related to European matters and taking a perspective that goes beyond national interests (Cremonesi et al., 2019; Gerhards, 2000; Koopmans and Erbe, 2004). The media can keep a neutral, negative or positive attitude towards the EU, mitigating or increasing Eurosceptic sentiments.

The use of the media, as demonstrated in numerous studies on political participation, is closely related to senses of political effectiveness perceived by citizens (Norris, 2000). In fact, the more citizens consume news and information about public affairs, the more likely it is for them to feel sure about their ability to understand politics (Kaid, McKinney, and Tedesco 2007) and thus take part in politics. That is why it is crucial to study the audience results obtained in the media in order to understand the transformations that have taken place in the public sphere (Trenz, 2004).

Empirical studies have so far identified television programmes with political interviews as the most favourable kind for spreading populist messages (Bos and Brants, 2014; Cranmer, 2011). It has also been shown that television news may bring about stronger emotions among the audience compared to the content of a newspaper (Namkoong et al., 2012). This is one reason to carry out academic research into the contribution from the main public television channel in Spain to the dynamics of Europeanisation in media coverage of EU matters. Such research is addressed in this article.

\section{INTERACTION AND POLITENESS IN POLITICAL DEBATES AND INTERVIEWS}

The political interview is a genre in itself. It is defined as the communication of information or opinion by public figures, experts or other people in the news for the benefit of the general public (Heritage and Greatbatch, 1991). It is a genre organised with two interlocutors - the interviewer and interviewee- who have an asymmetric relationship in which the journalist's discursive control interplays with the politician's social power in an exercise of negotiation linked to linguistic politeness (Cortés and Bañón, 1997; Hirsch, 1989). The political interview takes 
92 place between two interlocutors (first frame) but is designed for an external audience that is sometimes not even present (second frame), according to Fetzer and Weizman (2006). However, in the televised political interview carried out under audiovisual production, we can consider a third frame: the one defined by the production team, who make subjective choices in partitioning the time and space, as well as in the use of narrative elements that can modulate the resulting discourse.

One should keep in mind that the media (and especially television) play a key role in establishing the problems that concern citizens, as successive studies on "agenda setting" have shown (McCombs and Shaw, 1972; Rodríguez and Bouza, 2008; Iyengar and Kinder, 2010), and that in recent years there has also been a significant increase in the role of television as a privileged vehicle for staging alternative politics, conflicts, strategies, and debates of all kinds (López-García et al., 2015).

Live audiovisual debate with political leaders is made up of many intrinsic and extrinsic factors. The intrinsic factors are those related to journalistic discourse deriving from current affairs or with a specific editorial intentionality, whereas the extrinsic factors are those that create a staging, a mise en scène and a predetermined organisation of audiovisual production. In televised political interviews, politeness, neutrality, and cooperation can in principle be dissolved by deliberate action controlling the audiovisual discourse and the elements that make up the production.

The collectively participating audience with no physical presence, marking the discourse activity for both the interviewer and interviewee, is relegated to the party present in the third frame, in other words the producer, who is responsible for constructing the audiovisual discourse and who designs the audiovisual politeness as a fundamental element in dealing with the discourse. The objective of this study is to analyse audiovisual politeness by analysing the staging and audiovisual planning in televised debates produced by TVE during the election campaigns for the Government of Spain and the European Parliament in 2019.

In general, we understand politeness strategies to be a series of linguistic or discursive resources intended to minimise the impact of an act of speaking on the receiver (Brown and Levinson, 1987; Goldsmith, 2007, 2008). In specific terms, politeness is made up of "elements that are lexical, syntactic, morphological and even phonological (such as intonation), which serve the pragmatic purposes of establishing solidarity (i.e. closeness) with the listener or avoiding imposing on the listener. Depending on these purposes, we could talk about positive politeness as regards the former, and negative purposes for the latter" (Heffelfinger-Nieves, 2014: 97). Applied to the political sphere, Leech (1983) suggests the political interview is based on maintaining the principle of politeness. Politeness has been studied and accepted from different perspectives. Ferguson (1976: 43) indicates that politeness is shown in "daily routines like greetings, farewells and expressions of gratitude".

Recent studies suggest that intact gaze cueing is important for social function as Hayward and Ristic (2017) showed alterations in gaze cueing are associated with reduced social competence. Larger effects of gaze cueing were observed 
with fearful compared with neutral expressions (Holmes et al., 2010; Lassalle and Itier, 2013; Neath et al., 2013), and a similar effect with surprise (Bayless et al., 2011; Lassalle and Itier, 2013; Neath et al., 2013) and anger (Holmes et al., 2010; Lassalle and Itier, 2013) has been reported in studies measuring neural activity (Kaisler et al., 2020).

Advances in discourse analysis as a discipline have defined politeness as a cognitive model based on a series of expectations and representations constructed based on cultural norms and patterns that have been internalised through experience (Escandell-Vidal, 1988). For their part, Fraser (1990) and BargielaChiappini (2003) affirm that politeness is not only a way of using language, but is also part of grammar. They put forward that it is related to a conversational contract guided by a set of rights and obligations subject to negotiation.

More in keeping with this study, Charaudeau (2012) underlines the importance of other factors linked to the context, such as the specific purpose of the interaction, the participants' identities, the kind of exchange (personal or public) and the influence of collective imagination. Several studies have demonstrated that the journalistic interview, particularly of the political kind, seeks to create an atmosphere of confrontation (Clayman et al., 2006; Garcés, 2010; Mullany, 2002). On the other hand, Garcés-Conejos (2010) suggests that a journalist's impoliteness increases the more distant the interviewee's opinions are from those of society.

As Heffelfinger (2014) recalls, the explanation of politeness in communicative and also televised discourse, based on the model by Brown and Levinson (1987), is founded upon the concept of social image or "social face", the idealised way in which each person strives to be perceived and acts in front of others (Goffman, 1959, 1967). For Brown and Levinson (1987), anybody exposed to a public interview or debate has a "positive face" and another "negative face". The positive face is related to the desire to receive approval and appreciation of one's own image. The negative face is related to the freedom to act and the desire to not be imposed upon.

It is true that one of the norms of political interviews (Cuenca, 2013) is that the interviewer must keep a neutral stance, at least in appearance. However, in audiovisual interviews and fundamentally in ones that are broadcast live, together with the neutrality of the interviewee one has to consider the construction of the narrative by the production team, who are able to choose audiovisual constructs at a specific moment with which to transgress journalistic neutrality and the asymmetry between the interlocutors, thereby modifying the interaction.

In the same way that Fuentes-Rodríguez (2006), Fetzer and Bull (2008) and Cuenca (2013) put forward that the use of vocatives reveals the fight for discursive power between the interviewer and interviewee, acting as a thin line separating politeness from impoliteness, television production can lead to the discursive treatment being interpreted as polite or impolite.

The article proposes a method for measuring said audiovisual politeness. Using this method, it is shown that the production team, making use of its ability to choose the type of visual framing (point of view, composition, scaling) and sound framing (equalising, ambient sound, transitions), is an active party 
94 in constructing or destroying the interlocutor's image and in a possible implicit bolstering of the argumentation itself and image towards the public.

To sum up, audiovisual politeness is a strategic form of behaviour that the programme projects through its forms of audiovisual production, welcoming and handling the interviewee favourably sometimes and unfavourably other times. Studies on politeness in political interviews on television have been carried out by Brenes-Peña (2012), Christie (2002), Cuenca (2013), Mullany (2002) and Tanaka (2004, 2009), understanding politeness to be a strategic, intentional behaviour.

This study pays attention to the pragmatic implications arising from certain audiovisual constructs, especially the shot while listening $(\mathrm{S}(\mathrm{n}) \mathrm{L})$ and shot with split screen $(\mathrm{S}(\mathrm{n}) \mathrm{SS})$. The use of these strategies in televised debates among national political leaders proposed for the Spanish Congress and European Parliament shall be revealed in order to respond to the following hypothesis and research question:

- $\mathrm{H}_{1}$ : The televised debates with the candidates to the Spanish Congress and are addressed differently in audiovisual terms from those to the European Parliament.

- $\mathrm{RQ}_{1}$ : Is the audiovisual discourse used in carrying out the debate for the 2019 European elections more sedate, balanced and institutional than debate for the Spanish Congress?

\section{METHOD}

The debates broadcast during the elections for the Spanish Congress on 28 April 2019 and the European Parliament on 26 May are analysed here. The debate among candidates for Prime Minister was broadcast by RTVE ${ }^{1}$ on 22 April 2019, just six days before the election day. It was presented by Xavier Fortes (see Image 1). The debate itself lasted 100 minutes, though beforehand the build-up was broadcast with the candidates being welcomed and setting the scene, which lasted 53 minutes.

$1<$ http://www.rtve.es/alacarta/videos/especiales-informativos/especial-informativo-debate-cuatro/5159816/> (seen on 10/02/2020). 
Image 1. Candidates for Prime Minister of Spain

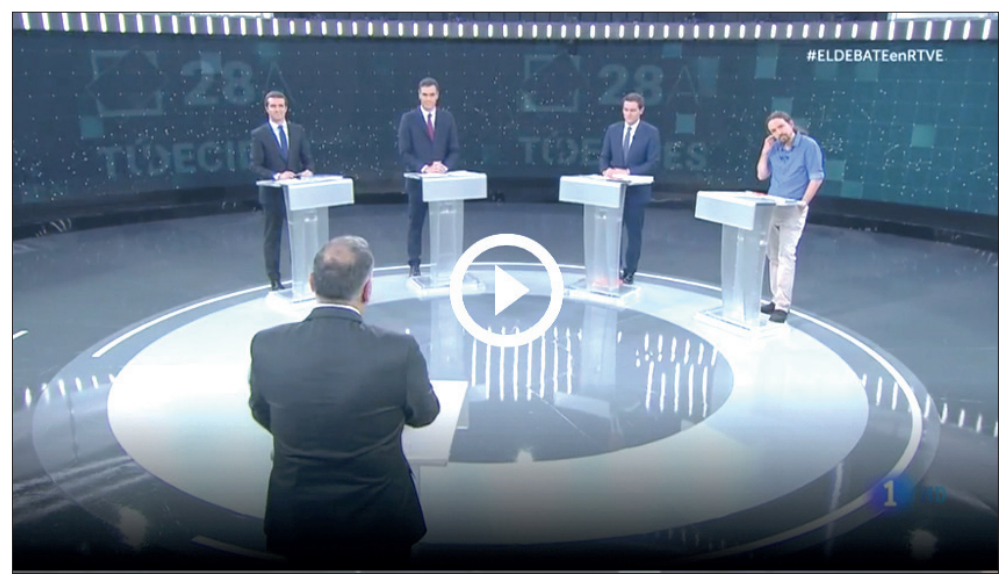

Source: RTVE.

The debate was organised into four blocks:

1. Economic, fiscal and employment policy: Pablo Casado began and Albert Rivera ended.

2. Social policy, the welfare state, pensions and equality: Albert Rivera began and Pablo Iglesias ended.

3. Territorial policy: Pedro Sánchez began and Pablo Casado ended.

4. Democratic regeneration and post-electoral pacts: Pablo Iglesias began and Pedro Sánchez ended. Each of the candidates had four and a half minutes per block.

The four-sided debate among Pedro Sánchez (Partido Socialista Obrero Español, moderate left), Pablo Casado (Partido Popular, moderate right), Pablo Iglesias (Unidas Podemos, hard left) and Albert Rivera (Ciudadanos, centre) was broadcast live on all RTVE channels.

As for the European political debate, $\mathrm{RTVE}^{2}$ broadcast the programme on 22 May, four days before the European elections, from Studio 1 in Prado del Rey in Madrid. It was also presented by Xavier Fortes (see Image 2). The public entity offered a nine-sided debate among candidates to the European Elections of 26 May. It lasted 120 minutes. There were three blocks in the debate on European policy:

1. Political and social Europe (immigration, territory, and welfare);

2. Economic and fiscal Europe;

2 <http://www.rtve.es/alacarta/videos/especiales-informativos/especial-informativo-debate-elecciones-europeas-26-2019/5233957/> (seen on 28/02/2020). 
3. European challenges. Each candidate had four minutes per block. In addition, they had one minute to round off, the order being established by lottery.

\section{Image 2. Candidates to the European elections}

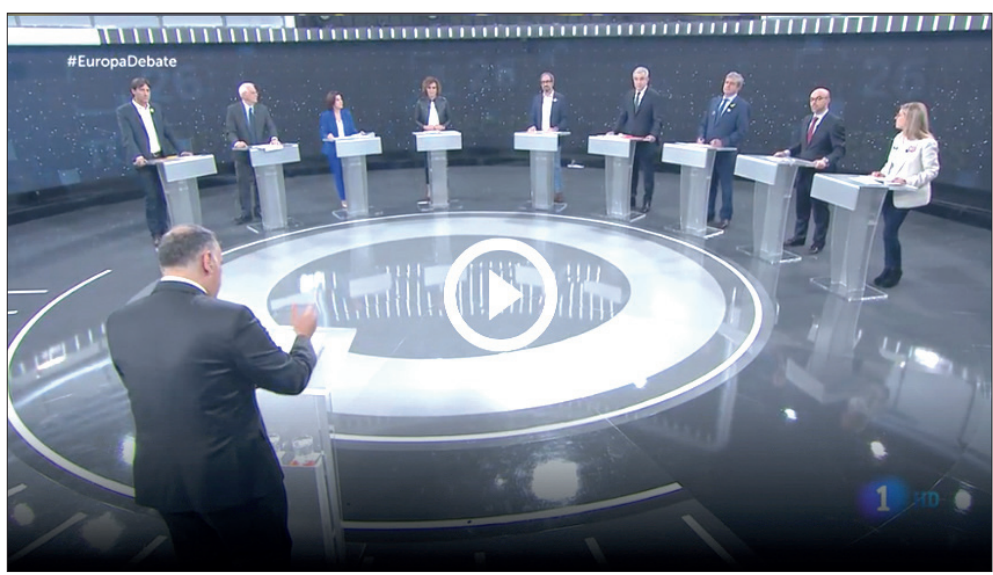

Source: RTVE.

The layout of both debates was staged identically, with the candidates in a semicircle and the presenter opposite them behind a transparent lectern. On both occasions there was also a backplane using a Steadicam (Image 3).

\section{Image 3. Backplane of the candidates}

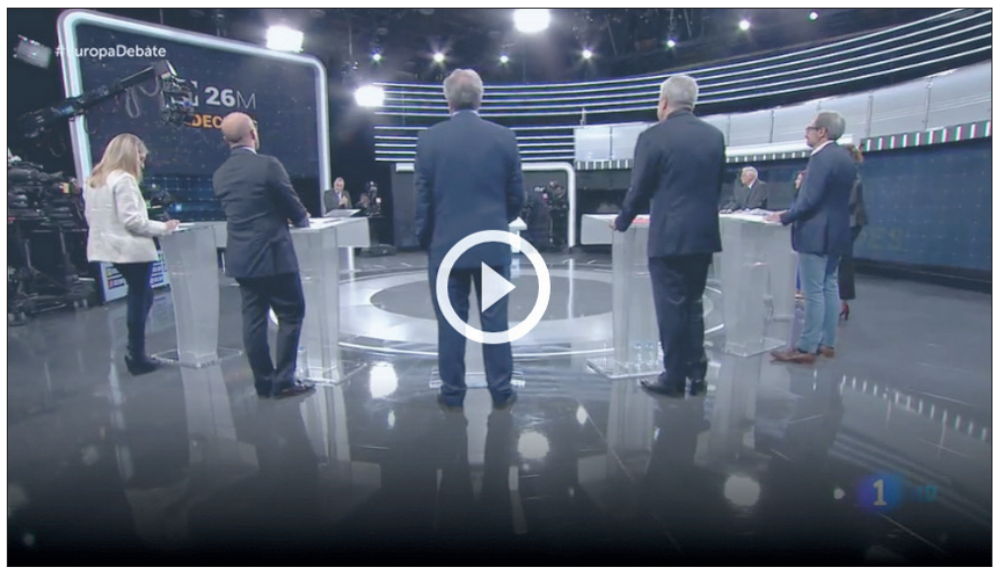

Source: RTVE.

A total of 30 spoken interventions about 10 topics in the debate in the Spanish Congress were analysed, and 42 interventions about 5 general topics in the European debate, making a total of 72 interventions in the two debates. 
In order to establish the intensity of the questions, a Likert scale was applied.

It was presented with an intensity of ten points (from $1=$ very positive, to 10 = very negative) in order to learn more precisely the level of intensity or difficulty in the question being put to the interviewee. The intensity variable of the questions has been determined based on previous research (Feldman and Kinoshita, 2019; Bavelas et al., 1990; Feldman, Kinoshita, and Bull, 2016). In order to avoid eventual mistaken readings due to the subjective nature in interpreting the intensity of the questions, it was necessary to measure the intercoder reliability with the help of two external codifiers who had not taken part in the initial codification. They independently analysed 40\% $(n=36)$ of the variables previously analysed (Tabachnick, Fidell, and Ullman, 2007). The minimum value obtained according to Scott's Pi formula was above 0.66. This value is high according to the classification by Landis and Koch (1977) for all the variables, with a mean value of 0.7248 (Neuendorf, 2012) being reached in all the variables. SPSS IBM v.21 was used for the statistical analysis.

\section{NARRATIVES}

The shots in the two debates were analysed taking into account the following audiovisual narratives (by the author Sánchez, 2018):

- $\mathrm{S}(\mathrm{n}) \mathrm{L}$ (Shot while listening). This is the audiovisual politeness conditioner and it can function as negative politeness (or negative face) when the question poses some difficulty for the interviewee (Heffelfinger-Nieves, 2014; Brown and Levinson, 1987). This type of question is made with a shot of the guest listening on the screen. In other words, the presenter asks the question offscreen while the interviewee to whom the question is being asked remains in the shot, or else during the guest's answer images are inserted that support such statements. A question of great political significance may be uncomfortable for the interviewee, so keeping them on the screen may create an uneasy situation for the guest and clear defencelessness before the audience (Elliot and Bull, 1996; Bavelas et al., 1988; Jucker, 1986), The uncomfortable situation of receiving an incisive question while being for example in a close-up shot, may lead to concerned or displeased gestures that may condition the audience's perception of the guest and the truth or not of their reply (Images 5 and 6). Likewise, the perception there may be of a reply may be conditioned by the images accompanying it. The nature of these images may lend the statements a "positive face" truthfulness, or they may be considered incoherent, due to the "negative face" images being seen by the audience. 
Image 4. Shot while listening

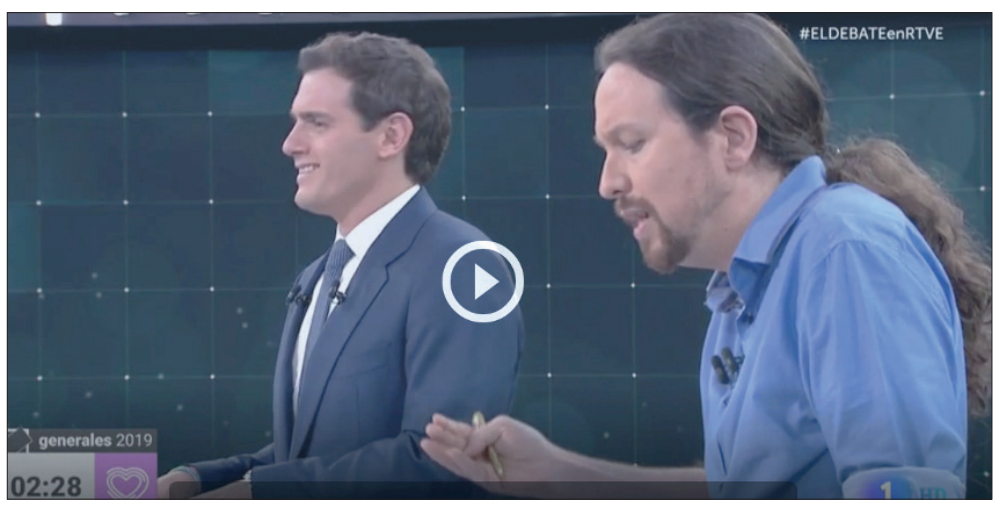

Source: RTVE.

Image 5. Shot while listening

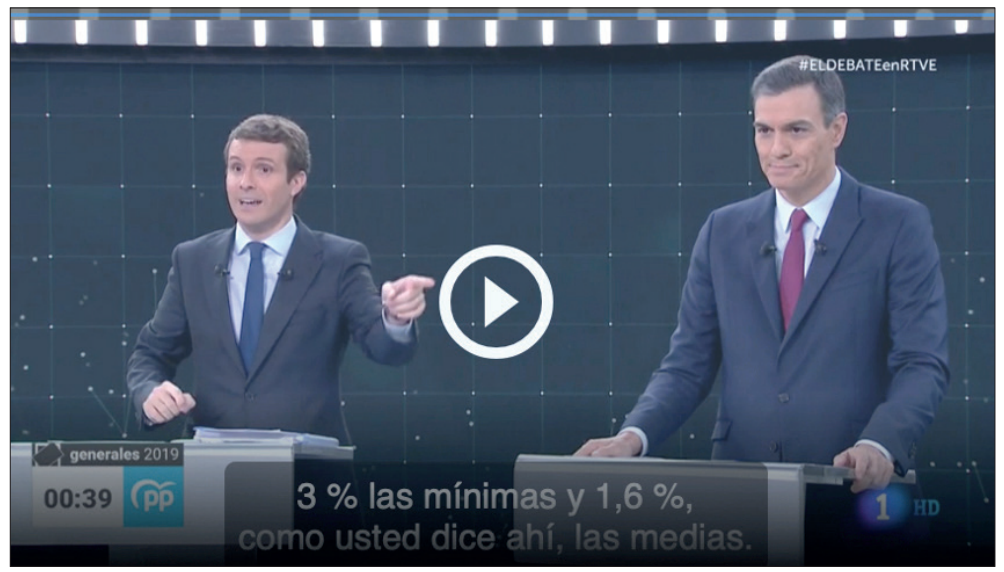

Source: RTVE.

- $(\mathrm{S}(\mathrm{n}) \mathrm{SS})$ (Shot with split screen). Dividing the screen between two or more candidates means, above all, dividing the audience's attention. Furthermore, this narrative solution manages to more efficiently guide aspects such as where the narrative is coming from and its intentionality. Moreover, it provides an evolution of the previous listening shot $\mathrm{S}(\mathrm{n}) \mathrm{L}$, since on the same screen it is possible to distinguish the cause and effect of the spoken intervention's intensity (Image 6). In the debates, it is possible to find shots with the screen split into two or more candidates in which only one is speaking (Images 6 and 7), or a multiple screen (Image 8). 
Image 6. Split screen

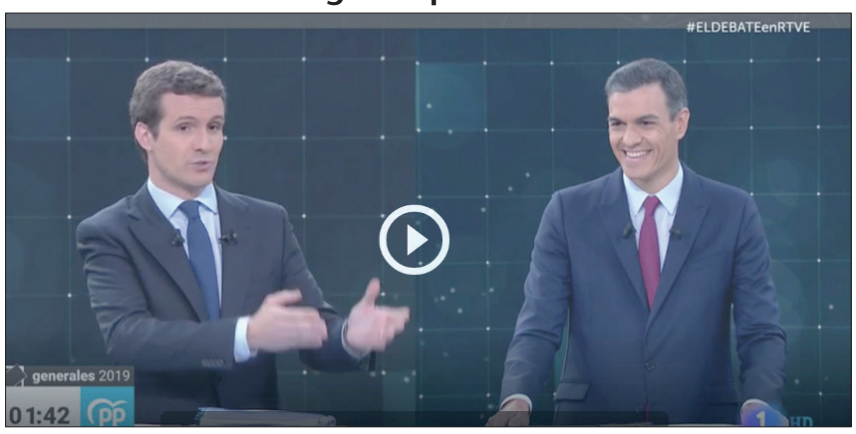

Source: RTVE.

Image 7. Split screen

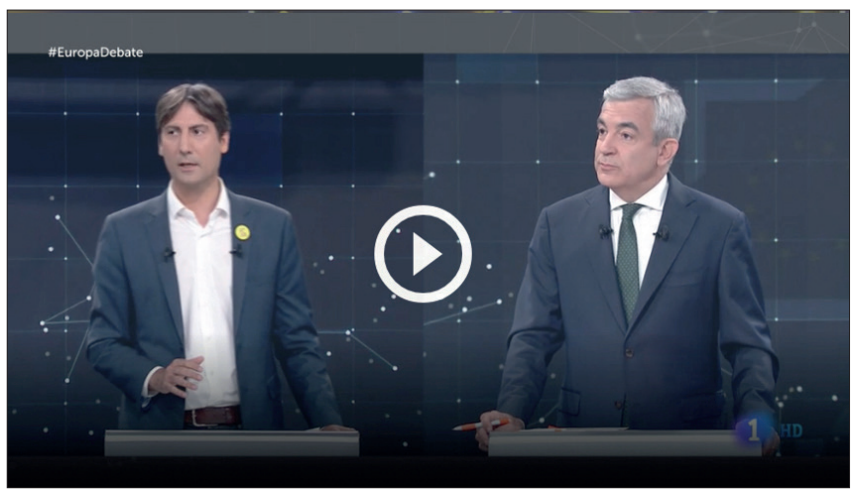

Source: RTVE.

Image 8. Multiple listening screen

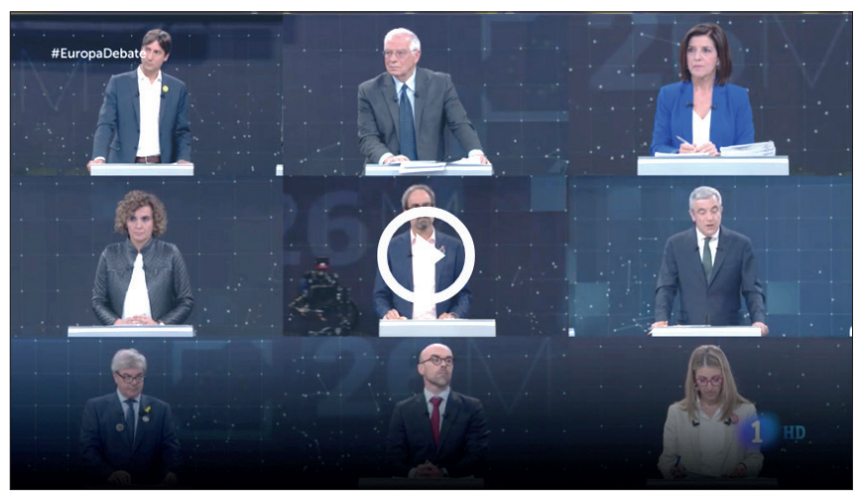

Source: RTVE. 


\section{RESULTS}

Table 1 shows the topics dealt with in the debate for Prime Minister of the Government and the intensity of the questions posed as a result of the Likert scale with the mean average (M) and standard deviation (SD). The same data is given in Table 2 for the European political debate.

In both Tables 1 and 2, the shots using split screens S(n)SS and the shots while listening S(n)L have been correlated using Pearson's coefficient ( $\mathrm{R} x-\mathrm{y}$ ) with the intensity of the questions. It should be noted that the positive or negative sign of the absolute result can vary between -1 and +1 , and a value of +1 is as strong as -1. In the former case, the relationship is positive, and in the latter it is negative.

According to Table 1, the correlation between the topics addressed with the related intensity and the divided shots $(S(n) S S)$ and listening shots $(S(n) L)$, there are significant and very sharp dependencies.

As regards matters regarding "Economic policies", a high correlation has been discovered with the visual formula of the split screen ( $\mathrm{r}[18]=.783, \mathrm{p}<.000)$ and somewhat less with the listening shots ( $\mathrm{r}[16]=.576, \mathrm{p}<.000)$. Another matter whose data gives a high correlation is "Employment" ( $\mathrm{r}[16]=.747, \mathrm{p}<.000)$ in the split screen and $(\mathrm{r}[19]=.264, \mathrm{p}<.000)$ in listening shots. Matters pertaining to "Pensions", whose questions obtained a very high mean $(\mathrm{M}=7.10$; $\mathrm{DT}=1.323)$, also obtained high correlations for the split screen (r [18]=.405, p <.000) and the shots while listening $(\mathrm{r}[18]=.621, \mathrm{p}<.000)$. The three most significant topics, "Economic policy, Employment and Pensions", show a positive correlation; i.e. the bigger the intensity of these debate topics, the greater the presence of the aforementioned audiovisual narrative proposals. With these considerations, the only topics with a negative sign are "Equality" ( $\mathrm{r}[16]=-.462, \mathrm{p}<.001)$ and $(\mathrm{r}$ $[18]=-.832, \mathrm{p}<.001)$; and "Electoral pacts" $(\mathrm{r}[18]=-.278, \mathrm{p}<.001)$ and $(\mathrm{r}[18]=$ $-.527, \mathrm{p}<.001)$.

As for the intensity of the questions posed in the national debate, the one concerning "Employment" policies stands out as the biggest $(\mathrm{M}=7.19$; $\mathrm{SD}=$ $1.342)$, whereas the least intensity is seen with "Electoral pacts" $(\mathrm{M}=5.10$; $\mathrm{SD}=$ 1.167).

Table 1. Debate for Prime Minister

\begin{tabular}{l|c|c|c} 
Topics & Intensity (M/SD) & S(n)SS & S(n)L \\
\hline Economic policy & $7.08 / 1.284$ & $.783^{* * *}$ & $.576^{* *}$ \\
\hline Fiscal policy & $6.20 / 1.385$ & $.432^{*}$ & $.881^{*}$ \\
\hline Employment & $7.19 / 1.342$ & $.747^{* * *}$ & $.264^{* * *}$ \\
\hline Social policy & $6.50 / 1.567$ & $0.836^{*}$ & .384 \\
\hline Welfare state & $6.90 / 1.256$ & .638 & $.354^{*}$ \\
\hline Pensions & $7.10 / 1.323$ & $.405^{* * *}$ & $.621^{* * *}$ \\
\hline Equality & $5.70 / 1.321$ & $-.462^{*}$ & -0.832 \\
\hline
\end{tabular}




\begin{tabular}{|c|c|c|c|}
\hline Topics & Intensity (M/SD) & $S(n) S S$ & $S(n) L$ \\
\hline Territorial policy & $5.80 / 1.298$ & .362 & $.287^{\star *}$ \\
\hline Democratic regeneration & $5.20 / 1.311$ & $.537^{\star}$ & .823 \\
\hline Post-electoral pacts & $5.10 / 1.167$ & -0.278 & $-0.527^{*}$ \\
\hline \multicolumn{4}{|l|}{ Total M: 6.27} \\
\hline \multicolumn{4}{|c|}{${ }^{*} \mathrm{p}<0.05,{ }^{* *} \mathrm{p}<.01,{ }^{* * *} \mathrm{p}<.001$} \\
\hline
\end{tabular}

The debate about European policy also provides very conclusive data as regards the significant dependence relationship between the topics debated and the visual methods used. The maximum intensity was obtained with questions concerning economic policies $(\mathrm{M}=6.20$; $\mathrm{SD}=1.267)$, and a minimum response $(\mathrm{M}=7.08 ; \mathrm{SD}=1.284)$ for the challenges that Europe must face in future. The visual methods used by the production team in the European debate show a higher relationship with "Social Europe" ( $\mathrm{r}[12]=.192, \mathrm{p}<.000)$ in the listening shots, as well as "Economic Europe" (r [12]= .536, p < .000) and $(\mathrm{r}[12]=.370$, $\mathrm{p}<.000)$.

Table 2. European policy debate

\begin{tabular}{l|c|c|c}
\multicolumn{1}{|c|}{ Topics } & Intensity (M/SD) & S(n)SS & S(n)L \\
\hline Political Europe & $5.80 / 1.289$ & 0.738 & $-0.835^{*}$ \\
\hline Social Europe & $6.10 / 1.359$ & $.368^{*}$ & $.192^{\star *}$ \\
\hline Economic Europe & $6.20 / 1.267$ & $.536^{* *}$ & $.370^{* *}$ \\
\hline Fiscal Europe & $5.50 / 1.212$ & 0.373 & $0.947^{*}$ \\
\hline European challenges & $4.80 / 1.387$ & $-.489^{*}$ & -0.834 \\
\hline
\end{tabular}

Total M: 5.68

${ }^{*} \mathrm{p}<0.05,{ }^{* *} \mathrm{p}<.01,{ }^{* * *} \mathrm{p}<.001$

Source: By the authors.

It is important to point out that, if each of the blocks is analysed separately, we can see that the block with greatest intensity in questions in the national debate is one point higher in intensity than the block with greatest intensity in the European elections. Extracting the means of intensity from both debates, in the national debate a mean average is obtained of $M=6.40$, and in the European policy debate it is $\mathrm{M}=5.68$.

In addition to this, there is the fact that there are more than twice the candidates in the European debate than in the national one, so it is understandable that it is more difficult for the audience to identify with the candidates. Thus, their level of emotional implication with what is being debated will also be lower. 


\section{DISCUSSION}

Spanish people's perspective of the European elections is somewhat contradictory: most admit that decisions taken by the European Union affect them quite a lot or a lot, but in spite of being aware of the important implications of European matters, over two thirds admit that they follow news about the elections to renew the European Parliament with little or no interest (CIS, 2019). The debate for Prime Minister of the Spanish Government broadcast by TVE's channel La 1 reached an audience of 7,246,000, meaning 35.8\% of the screen share (El País, $28 / 12 / 2019)$. The station's peak minute that day came in the same debate, with an audience of $7,881,000$. As for the debate for the European Parliament, the audience turned its back on the programme, also broadcast by TVE's La 1 at prime time. It only reached 817,000 people, meaning $5.2 \%$ of the screen share. The comedy series La que se avecina was that day's winner, with a share of $18.1 \%$.

This study is based on the initial hypothesis that television discourse with European content is different, not only in its content but also in the ways of presenting it audiovisually compared to local politics. The method used can be considered to have been tested on being applied to two decisive electoral processes with less than a month of difference between them, deciding on the makeup of their parliaments.

In order to carry out this analysis, the importance of the concept of audiovisual politeness has been taken into account, which could function jointly with linguistic politeness, which has already been studied previously (Feldman and Kinoshita, 2019; Bavelas et al., 1990; Feldman et al., 2016; Heritage and Greatbatch, 1991; McQuail, 1992).

After analysing the data obtained in this study, it is possible to point out a clear difference in the forms of televised representation between national and European debates. As a result of this difference, the perception obtained may increase the feeling of distance and relatively less importance as regards European political matters. The way Spanish citizens perceive the European political televised discourse seems to indicate that it is closer to slower, more institutional and less personalised representations. Hence, we can state that in the cases analysed the media discourse may help foster a lack of interest among citizens for certain matters by using an audiovisual language that makes identification difficult for the audience and thus increases their feeling of detachment. Questions in the European debate are perceived with less intensity than questions in the national debate, which may apparently feed a narrative with less audiovisual persuasion or pathos, understood as the emotions and the effect they may have on the audience as a rhetorical figure with the intention of achieving the effect of persuasion.

It is also necessary to point out the limitations of this study, especially those concerning the intentionality of the vote and its correlation with the difference in the modes of audiovisual representation. Future studies must address the dependent relationship between election results and the narrative forms of audiovisual representation, always taking into account the reciprocity between linguistic and audiovisual politeness. 
This research was supported by the national R\&D project Estrategias, agendas y discursos

en las cibercampañas electorales: medios de comunicación y ciudadanos (CSO201677331-C2-1-R), funded by the Spanish Ministry of Economy and Competitiveness for 2017-2020.

Sebastián Sánchez-Castillo (sebastian. sanchez@uv.es) is a Doctor in Audiovisual Communication. $\mathrm{He}$ is an Associate Professor at the University of Valencia and has published numerous studies into audiovisual persuasion, empathy with

Esteban Galán-Cubillo (egalan@upv. es) is a lecturer and researcher in the Communication, Art and Digital Culture group (ARTICOM). He has worked as an audiovisual storyteller and has over 15 years' experience as an audiovisual producer for different TV broadcasters. He has been

Arnau Gifreu-Castells (arnau.gifreu@eram.cat) is a Doctor in Communications and has a Master's Degree in Digital Arts (UPF, Spain). He has been a research affiliate at the Open Documentary Lab (MIT, 2013-2018) and a member of the i-Docs group (University of the West of England). Gifreu Castells is a member of the Medium research group (UPF). He coordinates interDocsBarcelona, the interactive section of the DocsBarcelona International Documentary fictional characters and the processes of audiovisual production. He has been a visiting lecturer at universities in Chile, Argentina, and the United Kingdom. He also worked at RTVV (Valencia regional public TV) from 1989 to 2013.

awarded several academic prizes like the 3rd place in the National Bachelor's Degree Award for Audiovisual Communication (2003) and he has produced articles, courses, lectures and presentations at international conferences about communication, transmedia, TV technologies and media.

Film Festival. He has also published in journals such as Studies in Documentary Film, Curator: The Museum Journal, Collection and Curation, Museum Management and Curatorship,, Lecture Notes on Computer Science, as well as in editorials like Wiley-Blackwell, Columbia University Press, Síntesis, etc. He is a lecturer at ERAM (University of Girona), Tecnocampus (UPF), Babeș-Bolyai University (Transylvania) and a visiting lecturer at EICTV (Cuba).

\section{References}

Banchoff, Thomas and Smith, Mitchell (2005). Legitimacy and the European Union: The Contested Polity. London, UK: Routledge.

Bargiela-Chiappini, Francesca (2003). "Face and Politeness: New (Insights) for Old
(Concepts)". Journal of Pragmatics, 35(10), pp. 1453-1469.

Bavelas, Janet; Black, Alex; Bryson, Lisa, and Mullett, Jennifer (1988). "Political Equivocation: A Situational Explanation". Journal 
of Language and Social Psychology, 7, pp. 137145.

Bavelas, Janet; Black, Alex; Chovil, Nicole, and Mullet, Jennifer (1990). Equivocal Communication. Newbury Park: Sage.

Bayless, Sarah; Glover, Missy; Taylor, Margot, and Itier, Roxane (2011). "Is It in the Eyes? Dissociating the Role of Emotion and Perceptual Features of Emotionally Expressive Faces in Modulating Orienting to Eye Gaze". Visual Cognition, 19(4), pp. 483-510. <https:// doi.org/10.1080/13506285.2011.552895>.

Bobba, Giuliano and Seddone, Antonella (2018). "How do Eurosceptic Parties and Economic Crisis Affect News Coverage of the European Union? Evidence from the 2014 European Elections in Italy". European Politics and Society, 19(2), pp. 147-165.

Bos, Linda and Brants, Kees (2014). "Populist Rhetoric in Politics and Media: A Longitudinal Study of the Netherlands". European Journal of Communication, 29(6), pp. 703-719. <https://doi.org/10.1177/0267323114545709>

Brenes-Peña, María Ester (2012). "Género, discurso político y descortesía verbal: Análisis de la influencia de la variante sexo en el Parlamento Andaluz". Philologia Hispalensis, 26, pp. 59-77.

Brown, Penelope and Levinson, Stephen (1987). Politeness: Some Universals in Language Usage. Cambridge: Cambridge University Press.

Brüggemann, Michael and Schulz-Forberg, Hagen (2009). "Becoming Pan-European? Transnational Media and the European Public Sphere". The International Communication Gazette, 71(8), pp. 693-712.

Cayrol, Roland (1991). "European Elections and the Pre-Electoral Period. Media Use and Campaign Evaluations". European Journal of Political Research, 19(1), pp. 17-29.

CIS, Centro de Investigaciones Sociológicas (2019). "Barómetro Postelectoral. Elecciones Generales 2019. Avance de resultados". Estudio núm. 3269, noviembre-diciembre. Available at: <http://datos.cis.es/pdf/Es3269ccaa_A.pdf >. Accessed 10 May 2020.
Charaudeau, Patrick (2012). "Problemas teóricos y metodológicos en los estudios de la oralidad aplicados a la cortesía: Aspectos lingüísticos, pragmáticos y discursivos." In: Escamilla, Julio and Henry, Grandfield (eds.). Miradas multidisciplinares a los estudios de cortesía y descortesía en el mundo hispánico. Barranquilla: University of Atlántico, pp. 13-32.

Christie, Chris (2002). "Politeness and the Linguistic Construction of Gender in Parliament: An Analysis of Transgressions and Apology Behavior". Working Papers on the Web, 3. Available at: <https://extra.shu.ac.uk/wpw/ politeness/christie.htm>. Accessed 19 June 2020.

Clayman, Steven; Elliott, Marc; Heritage, John, and McDonald, Laurie (2006). "Historical Trends in Questioning Presidents, 19532000". Presidential Studies Quarterly, 36(4), pp. 561-583.

Cortés, Luis and Bañón, Antonio (1997). Comentario lingüístico de textos orales II. El debate y la entrevista. Madrid: Arco/Libros.

Cranmer, Mirjam (2011). Populist Communication and Publicity: An Empirical Study of Contextual Differences in Switzerland. Swiss Political Science Review, 17(3), pp. 286-307. <https://doi.org/10.1111 /j.1662-6370.2011.02019.x>

Cremonesi, Cristina; Seddone, Antonella; Bobba, Giuliano, and Mancosu, Moreno (2019). "The European Union in the Media Coverage of the 2019 European Election Campaign in Italy: Towards the Europeanization of the Italian Public Sphere". Journal of Modern Italian Studies, 24(5), pp. 668-690.

Cuenca, Maria Josep (2013). "Uso del vocativo en la entrevista política: Género discursivo y (des)cortesía". Discurso y Sociedad, (3), pp. 522-552.

El País (2019). "La 1 cierra 2019 con su peor dato histórico anual de audiencia". Available at: <https://cutt.ly/MfIxJVN>. Accessed 25 June 2020.

Elliott, Judy and Bull, Peter (1996). "A Question of Threat: Face Threats in Ques- 
tions Posed During Televised Political Interviews". Journal of Community Applied Social Psychology, 6(1), pp. 49-72.

Eriksen, Erik Oddvar and Fossum, John Erik (2004). "Europe in Search of Legitimacy: Strategies of Legitimation Assessed". International Political Science Review, 25(4), pp. 435459.

Escandell-Vidal, Victoria (1998). "Politeness: A Relevant Issue for Relevance Theory". Revista Alicantina de Estudios Ingleses, (11), pp. 45-57.

Feldman, Ofer and Kinoshita, Ken (2019). "Ignoring Respect: The Effects of Threat to Face on Replies and the Ensuing Questions During Broadcast Political Interviews in Japan". Journal of Language and Social Psychology, 38(5-6), pp. 606-627.

Feldman, Ofer; Kinoshita, Ken, and Bull, Peter (2016). "Ducking and Diving: How Political Issues Affect Equivocation in Japanese Political Interviews". Japanese Journal of Political Science, 17, pp. 141-167.

Ferguson, Charles (1976). "The Structure and Use of Politeness Formulas". Language in Society, 5(02), pp. 137-151.

Fetzer, Anita and Bull, Peter (2008). "Well, I Answer it by Simply Inviting You to Look at the Evidence. The Strategic Use of Pronouns in Political Interviews". Journal of Language and Politics, (712), pp. 271-289.

Fetzer, Anita and Weizman, Elda (2006). "Political Discourse As Mediated and Public Discourse". Journal of Pragmatics, (38), pp. 143-153.

Fraser, Bruce (1990). "Perspectives on Politeness". Journal of Pragmatics, 14(2), pp. 219-236.

Fuentes-Rodríguez, Catalina (2006). “¿Cortesía o descortesía? La imagen del entrevistado vs. La imagen del entrevistador". Cultura, Lenguaje y Representación, (3), pp. 73-88.

Galpin, Charlotte and Trenz, Hans-Jörg (2018). "Rethinking First- and Second-Order Elections Media Negativity and Polity Contestation During the 2014 European Parliament Elections in Germany and the UK". Presented at ARENA Working Paper 3/2018.
Garcés-Conejos, Pilar (2010). "A Gender Approach to the Study of Im-politeness". International Review of Pragmatics, (2), pp. 46-94.

Gerhards, Jürgen (2000). "Europäisierung von Ökonomie und Politik und Die Trägheit der Entstehung einer Europäischen Öffentlichkeit". Die Europäisierung Nationaler Gesellschaften. Sonderheft, 40(2000), pp. 277-305.

Gleissner, Martin and Vreese, Claes de (2005). "News about the EU Constitution: Journalistic Challenges and Media Portrayal of the European Union Constitution". Journalism, 6(2), pp. 221-242.

Goffman, Erving (1959). The Presentation of Self in Everyday Life. Garden City: Doubleday.

-. (1967). Interaction Ritual: Essays on Faceto-Face Behavior. Garden City: Anchor Books.

Goldsmith, Daena (2007). "Brown and Levinson's Politeness Theory". In: Whaley, Bryan and Samter, Wendy (eds.). Explaining Communication: Contemporary Theories and $E x-$ emplars. Mahwah: Erlbaum, pp. 243-262.

-. (2008). Politeness Theory. In: Braithwaite, Dawn and Schrodt, Paul (eds.). Engaging Theories in Interpersonal. California: Sage, pp. 255-269.

Hayward, Dana and Ristic, Jelena (2017). "Feature and Motion-based Gaze Cuing Is Linked with Reduced Social Competence". Scientific Reports, (7), no. 44221.

Heffelfinger-Nieves, Cristal (2014). "Cortesía y construcción de género en 10 entrevistas políticas de la televisión puertorriqueña". Diálogo de la Lengua, (6), pp. 95-115.

Heritage, John and Greatbatch, David (1991). "On the Institutional Character of Institutional Talk: The Case of News Interview Interaction". In: Boden, Deirdre and Zimmerman, Don (eds.). Talk and Social Structure. Berkeley: University of California Press, pp. 93-137.

Highfield, Tim; Harrington, Stephen, and Bruns, Axel (2013). "Twitter As a Technology for Audiencing and Fandom: The \#Eurovision Phenomenon". Information, Communication \& Society, 16(3), pp. 315-339. 
Hirsch, Richard (1989). Argumentation, Information, and Interaction: Studies in Face-toface Interactive Argumentation Under Differing Turn-taking Conditions. Gothenburg Monographs in Linguistics 7. Department of Linguistics: University of Göteborg.

Hobolt, Sara and Wittrock, Jill (2011). "The Second-order Election Model Revisited: An Experimental Test of Vote Choices in European Parliament Elections". Electoral Studies, 30(1), pp. 29-40.

Holmes, Amanda; Mogg, Karin; Garcia, Laura, and Bradley, Brenda (2010). "Neural Activity Associated with Attention Orienting Triggered by Gaze Cues: A Study of Lateralized ERPs". Society for Neuroscience, 5(3), pp. 285-295.

Hutter, Swen and Kriesi, Hanspeter (2019). "Politicizing Europe in Times of Crisis". Journal of European Public Policy, 26(7), pp. 996-1017.

Iyengar, Shanto and Kinder, Donald (2010). News That Matters: Television and American Opinion, Updated Edition. Chicago: Chicago University Press.

Jucker, Andreas (1986). News Interviews: A Pragmalinguistic Analysis. Amsterdam: Gieben.

Kaid, Lynda; McKinney, Mitchell, and Tedesco, John (2007). "Political Information Efficacy and Young Voters". American Behavioral Scientist, (50), pp. 1093-1117.

Kaisler, Raphaela; Marin, Manuela, and Leder, Helmut (2020). "Effects of Emotional Expressions, Gaze, and Head Orientation on Person Perception in Social Situations". SAGE Open, 10(3).

Königslöw, Katharina (2012). "Europe in Crisis? Testing the Stability and Explanatory Factors of the Europeanization of National Public Spheres". International Communication Gazette, 74(5), pp. 443-463.

Koopmans, Ruud (2007). "Who Inhabits the European Public Sphere? Winners and Losers, Supporters and Opponents in European Political Debates". European Journal of Political Research, 46(2), pp. 183-210.

Koopmans, Ruud and Erbe, Jessica (2004). "Towards a European Public Sphere? Vertical and Horizontal Dimensions of Europeanized Political Communication, Innovation". The European Journal of Social Science Research, 17(2), pp. 97-118.

Kriesi, Hanspeter (2016). "The Politicization of European Integration". Journal of Common Market Studies, 54(3), pp. 32-47.

Landis, Richard and Koch, Gary (1977). "The Measurement of Observer Agreement for Categorical Data". Biometrics, pp. 159-174.

Lassalle, Amandine and Itier, Roxane (2013). "Fearful, Surprised, Happy, and Angry Facial Expressions Modulate Gaze-oriented Attention: Behavioral and ERP Evidence". Society for Neuroscience, 8(6), pp. 583-600.

Leech, Geoffrey (1983). Pragmatics, Discourse Analysis, Stylistics and "the Celebrated Letter. London. New York: Longman.

López-García, Guillermo; Llorca-Abad, Germán; Valera-Ordaz, Lydia, and Peris-Blanes, Àlvar (2015). "Los debates electorales, ¿el último reducto frente la mediatización? Un estudio de caso de las elecciones generales españolas de 2015". Palabra Clave, 21(3), pp. 772-797.

Lord, Christopher and Beetham, David (2002). "Legitimizing the EU: Is There a 'Postparliamentary Basis' for Its Legitimation?". Journal of Common Market Studies, 39(3), pp. 443-462.

Maier, Michaela; Strömbäck, Jesper, and Kaid, Lynda (2011). Political Communication in European Parliamentary Elections. Farnham: Ashgate Publishing, Ltd.

Marsh, Michael (1998). "Testing the Second-order Election Model After Four European Elections". British Journal of Political Science, 28(4), pp. 591-607.

McCombs, Maxwell and Shaw, Donald (1972). "The Agenda Setting Function of the Mass Media". Public Opinion Quarterly, 36(2), pp. 176-187.

McQuail, Denis (1992). Media Performance. London: Sage.

Mullany, Louise (2002). "I Don't Think You Want Me to Get a Word in Edgeways Do 
You John? Re-assessing (Im)Politeness, Language and Gender in Political Broadcast Interviews". Working Papers on the Web. Available at: <https://extra.shu.ac.uk/wpw/politeness/ mullany.htm>. Accessed 19 June 2020.

Namkoong, Kang; Fung, Timothy, and Scheufele, Dietram (2012). "The Politics of Emotion: News Media Attention, Emotional Responses, and Participation During the 2004 US Presidential Election". Mass Communication \& Society, 15(1), pp. 25-45.

Neath, Karly; Nilsen, Elizabeth; Gittsovich, Katarzyna, and Itier, Roxane (2013). "Attention Orienting by Gaze and Facial Expressions Across Development". Emotion, 13(3), pp. 397-408.

Neuendorf, Kimberly (2012). The Content Analysis Guidebook. Thousand Oaks: Sage Publications.

Norris, Pippa (2000). A Virtuous Circle: Political Communications in Postindustrial Societies. Cambridge, UK: Cambridge University Press.

Pfetsch, Barbara; Adam, Silke, and Eschner, Barbara (2008). "The Contribution of the Press to Europeanization of Public Debates: A Comparative Study of Issue Salience and Conflict Lines of European Integration". Journalism, 9(4), pp. 465-492.

Porte, Caroline de la and Dalen, Arjen van (2016). "Europeanization of National Public Spheres? Cross-National Media Debates About the European Union's Socio-economic Strategy". European Politics \& Society, 17(3), pp. 279293.

Reif, Karlheinz and Schmitt, Hermann (1980). "Nine Second-order National Elections - A Conceptual Framework for the Analysis of European Election Results". European Journal of Political Research, 8 (1), pp. 3-44.

Reif, Karlheinz; Schmitt, Hermann, and Norris, Pippa (1997). "Second-order Elections". European Journal of Political Research, 31(1-2), pp. 109-124.

Risse, Thomas and Steeg, Marianne van de (2003). “An Emerging European Public Sphere? Empirical Evidence and Theoretical Cla- rifications". Presented at Europeanisation of Public Spheres, Political Mobilisation, Public Communication and the European Union, Conference. Science Center Berlin, 20-22 June.

Rodríguez, Raquel and Bouza, Fermín (2008). "Cambios en las agendas y cambios en la comunicación política". In: Canel, María José and García, Mario (eds.). Estudios de Comunicación Política, pp. 45-64.

Sánchez-Castillo, Sebastián (2018). "Cortesía audiovisual en la entrevista política". Communication \& Society, 31(2), pp. 137-153.

Schmitt, Hermann (2005). "The European Parliament Elections of June 2004: Still Second Order?". West European Politics, 28 (3), pp. 650-679.

Segesten, Anamaria and Bossetta, Michael (2019). "The Eurosceptic Europeanization of Public Spheres: Print and Social Media Reactions to the 2014 European Parliament Elections". Comparative European Politics, 17(3), pp. 361-379.

Statham, Paul (2008). "Making Europe News: How Journalists View Their Role and Media Performance". Journalism, 9(4), pp. 398422 .

Statham, Paul and Trenz, Hans-Jörg (2012). The Politicization of Europe: Contesting the Constitution in the Mass Media. London: Routledge.

Tabachnick, Barbara; Fidell, Linda, and Ullman, Jodie (2007). Using Multivariate Statistics. Vol. 5. Boston: Pearson.

Tanaka, Lidia (2004). Gender, Language and Culture: A Study of Japanese Television Interview Discourse. Philadelphia: John Benjamins Publishing.

—. (2009). "Communicative Stances in Japanese Interviews: Gender Differences in Formal Interactions". Language \& Communication, 29(4), pp. 366-382.

Trenz, Hans-Jörg (2004). "Media Coverage on European Governance: Exploring the European Public Sphere in National Quality Newspapers". European Journal of Communication, 19(3), pp. 291-319. 
Tsakatika, Myrto (2007). "Governance vs. Politics: The European Union's Constitutive 'Democratic Deficit". Journal of European Public Policy, 14(6), pp. 867-885.

Vreese, Claes de; Banducci, Susan; Semetko, Holli, and Boomgaarden, Hajo (2006). "The News Coverage of the 2004 European Parliamentary Election Campaign in 25 Countries". European Union Politics, 7(4), pp. 477504.

Vreese, Claes de; Lauf, Edmun, and Peter, Jochen (2007). "The Media and European
Parliament Elections: Second-rate Coverage of a Second-order Event?". In: Brug, Wouter van der and Eijk, Cees van der (eds.). European Elections and Domestic Politics. Lessons from the Past and Scenarios for the Future. Notre Dame: University of Notre Dame Press, pp. 116-130.

Wilde, Pieter de (2011). "No Polity for Old Politics? A Framework for Analyzing the Politicization of European Integration". Journal of European Integration, 33(5), pp. 559-575. 